№ 06-2412вн) // СПС «КонсультантПлюс». URL: http:// http:// www.consultant.ru/document/cons_doc_LAW_57872 (дата обращения: 04.04.2019).

13. Письмо Рособрнадзора от 16 апр. 2015 г. № 01-50174/07-1968 «О приеме на обучение лиц с ограниченными возможностями здоровья» // СПС «КонсультантПлюс». URL: http:// http://www.consultant.ru/document/cons_doc_LAW_ 178696 (дата обращения: 04.04.2019).

УДК 37.02

Науч. спец.: 13.00 .01

DOI: 10.36809/2309-9380-2020-26-87-89

\section{ФОРМИРОВАНИЕ ГАРМОНИЧНО РАЗВИТОЙ ЛИЧНОСТИ СРЕДСТВАМИ НАЦИОНАЛЬНОГО ВИДА СПОРТА}

В статье обосновывается педагогическая роль национальной культуры как средства духовно-нравственного воспитания молодежи. Автор доказывает, что наиболее приемлемым на сегодняшний день в системе школьной образовательной среды является метод формирования гармонично развитой личности на основе национального вида спорта того или иного народа. В данной работе впервые апробирована программа освоения национальной борьбы башкирского народа в рамках урочной деятельности.

Ключевые слова: гармонично развитая личность, духовно-нравственное воспитание, борьба куреш.
14. Алехина С. В., Алексеева М. Н., Агафонова Е. Л. Готовность педагогов как основной фактор успешности инклюзивного процесса в образовании // Психологическая наука и образование. 2011. № 1. С. 83-91.

15. Айбазова М. Ю., Лавринец К. Ю. Подготовка будущих учителей к работе в условиях инклюзивного образования // Педагогика. 2014. № 5. С. 82-86.

(С Айбазова М. Ю., Кантлокова Ф. Р., 2020

A. Kh. Akhmedyanova

\title{
FORMATION OF A HARMONIOUS PERSONALITY BY MEANS OF A NATIONAL SPORT
}

The article substantiates the pedagogical role of the national culture as a means of spiritual and moral education of young people. The author proves that the most acceptable method in the system of school educational environment is the method of forming a harmoniously developed personality based on a national sport of a particular nation. In this work, for the first time, the program for mastering the national wrestling of the Bashkir people as part of the regular lesson activities was tested.

Keywords: harmoniously developed personality, spiritual and moral education, wrestling kuresh.

На сегодняшний день глобальной проблемой является сохранение генофонда человеческой цивилизации, основу которого составляет подрастающее поколение. Возникновение данной проблемы связано с активным внедрением в жизнь общества информационно-коммуникационных технологий, которые обеспечили благоприятные условия для развития таких болезней в среде молодежи, как интернетзависимость и лень.

Информационная революция вовлекла «неокрепшие души» подрастающего поколения «в информационное противоборство, пропагандирующее общество высокого потребления, где легкими путями получают все блага цивилизации, роскошь, вседозволенность, закрепление ценностей массовой культуры» [1, с. 123]. Всё это может привести в дальнейшем к краху духовно-нравственного воспитания подрастающего поколения; уничтожению семейных и национальных ценностей; стиранию исторической памяти; потере значимости семьи как главного института гармоничной социализации личности. Современная молодежь будет активно внедряться в боевые радикальные группировки, ее уже сейчас учат использовать террористические методы с целью разжигая межэтнических и межконфессиональных конфликтов.

Поэтому очень важно осознать тот факт, что «во все периоды истории человечество спасали твердость духа, спокойствие души, здравый ум и крепость тела, которые закаливались в борьбе с суровым климатом, в борьбе за выживание, в борьбе за то, чтобы жить счастливо, творить, растить потомство, воспитывать детей здоровыми, высоконравственными и моральными личностями» [2, с. 24].

Национальный вид спорта является одним из главных компонентов народной педагогики. Этот вид спорта несет в себе отголоски прошлого: мудрость, базовые духовнонравственные, национальные и общечеловеческие ценности. Его присутствие в современной воспитательной системе позволяет легко и доступно сохранять связь подрастающего поколения с предками, формировать национальный менталитет и овладевать культурно-историческими достояниями народа. На сегодняшний день национальный вид спорта того или иного народа должен быть направлен на борьбу с физиологической стагнацией детей и с духовным застоем, чтобы предотвратить развитие агрессии, депрессии, суицида, безделья, умственной отсталости, безнравственности. Как утверждал Л. Н. Толстой, «надо непременно встряхивать себя физически, чтобы быть здоровым морально» (цит. по: [3, с. 101]). М. Монтень доказывал: «Без здоровья меркнут и гибнут радость, мудрость, знания и добродетель» [4, с. 412]. Национальный вид спорта народа - это один из методов формирования подвижной, активной, здоровой, творческой, интеллектуальной, гармонично развитой личности ребенка. 
Актуальность национальной культуры в формировании гармонично развитой личности отметил в свое время Г. Н. Волков: «...народ в наиболее чистом виде всегда представляют дети, основа воспитания которых заложена в национальной культуре, играх, спортивных состязаниях, традициях и обычаях народа, а когда национальное не приживается и умирает в детях, то это означает начало смерти самой нации» [5, с. 97].

Исходя из доводов в пользу национального вида спорта как неотъемлемой части воспитательной системы и национальной культуры, мы разработали программу формирования гармонично развитой личности обучающегося школы средствами башкирской национальной борьбы куреш (курэш), которая характерна для нашего региона - Республики Башкортостан. Главную идею программы составила воспитательно-образовательная система японских школ, в которых национальная культура основана на национальных видах единоборств, таких как дзюдо, карате-до, айкидо, являющихся базовой основой формирования гармонично развитой личности школьников Японии.

Данные виды единоборств преподаются в японских школах как отдельные предметы, которые формируют следующие компоненты личности ученика: народную философию, знание отечественной истории, основы морали, этики и эстетики, базовые ценности, почитание духа предков и уважение к старшим, спокойствие, дисциплинированность, целеустремленность, сохранение внутренней и внешней гармонии, созидание и развитие миропорядка. Педагогическая национальная культура обеспечивает статус Японии как одной из самых здоровых наций с высоким человеческим потенциалом, так как основная духовная суть единоборств - «научить детей навыкам борьбы, которая противостоит кулачным боям, кровопролитию, и дать понять, что борьба имеет философскую суть, которая заключается в умении обладать собой, иметь силу воли, быть трудолюбивым, стремиться к созданию гармонии в мире и вокруг себя» [6, с. 128].

Национальная борьба башкирского народа куреш также по своей сути философична, аксиологична и носит экзистенциальный характер. Первые архаичные отголоски борьбы куреш запечатлены в национальном башкирском эпосе «Урал-батыр». Здесь главный герой Урал-батыр наделен всеми духовно-нравственными качествами, которыми должен обладать настоящей башкирский батыр, сын, отец: это духовность, любовь к Родине, готовность к борьбе за бытие своего народа, его культуру, за гармоничный миропорядок, борьбе против пагубных явлений в обществе, борьбе за счастливую и здоровую жизнь.

О философско-аксиологической и духовной основе борьбы куреш писал (и практиковал ее в своей религиозной школе) наш земляк, башкирский просветитель и теолог Зайнулла-ишан Расулев. Народная память хранит следующее предание о его тренерских занятиях с одним шакирдом: «Однажды шакирд Зайнуллы-ишана - Габьямин Касимов, 1870 года рождения, вышел помериться силами с казахским батыром. Этот шакирд был невысокого роста, худощав. Конечно, он проиграл казаху. После проигранного поединка Зайнулла-ишан повез этого шакирда в лес. В лесу он нашел огромный камень и приказал Габьямину его поднять.
Шакирд пытался сдвинуть камень, но ничего не вышло. Тогда Зайнулла-ишан сказал, чтоб Габьямин не отчаивался хорошее питание и постоянные тренировки принесут ему победу. Немного погодя он вновь привез Габьямина к тому камню. Приказал поднять камень. Но Габьямин лишь смог в этот раз сдвинуть его. Спустя какое-то время они вновь прибыли к этому камню. Зайнулла-ишан сказал: “Еще раз, сынок, попробуй поднять камень!" Габьямин поднял камень до щиколотки. А уж в четвертый раз придя к камню, Габьямин смог поднять его до колен. Зайнулла-ишан обрадовался и решил устроить вновь состязания по борьбе куреш с казахским батыром. Итак, день состязания наступил. Собрался народ, в центре майдана стоит Габьямин. Ждут казахов. И вот смотрят: ведут в цепях своего батыра казахи. Он, в свою очередь, рычит, рвет землю руками, наводя ужас на народ. Зайнулла-ишан, прочитав молитву, вручил полотенце шакирду. Борьба началась. Тяжело было Габьямину, уж очень был огромен и толст казахский батыр. Шакирд его крутил, валил, кидал. Но соперник был силен. Габьямин собрался духом, вспомнил, как и чему учил его учитель, вспомнил, с какой легкостью поднял в последний раз камень до колен, и, так же подняв казаха, повалил его на землю. Зайнулла-ишан подошел к Габьямину и назвал его Батыром» [7, с. 103]. Таким образом, ученый-педагог Зайнулла-ишан в своем медресе с целью сохранения и закрепления духовно-нравственных связей молодежи с их предками, с целью формирования крепкого духа, здорового тела и здравого ума практиковал на своих занятиях традиционные башкирские игры и тренировал своих шакирдов в борьбе куреш.

Сила духовного и физического воспитания методами национальных видов борьбы присутствует и в восточных единоборствах. Например, «один из самых популярных видов единоборств Японии, получивший статус олимпийского боевого искусства, дзюдо, превратил основателя данной школы единоборств, Дзигоро Кано, из болезненного мальчика в здорового» [6, с. 13].

В рамках урочной деятельности возможно использование стратегического потенциала национальной борьбы куреш как духовно-нравственного ресурса формирования гармоничной, здоровой и мудрой личности. Наша программа основана на национально-региональном компоненте в соответствии с Федеральным государственным образовательным стандартом основного общего образования.

Программа реализуется по следующему принципу: практикование национальной башкирской культуры в межпредметной взаимосвязи с национальной борьбой куреш с целью познания не только практической, но и теоретической ее части (см. табл.).

Отметим, что предложенная программа была удачно апробирована с 2009 по 2019 г. в 9а классе Башкирского лицея № 1 г. Учалы Республики Башкортостан. Экспериментальный 9а класс обозначили как класс «Батыров». Состав класса - 15 мальчиков и 16 девочек, 100 \% башкир. Впоследствии все выпускники класса продолжили обучение. В основном выпускники 9а класса поступили в колледжи нашей республики на факультеты фризической культуры и спорта, башкирской филологии, истории и журналистики и в медресе. 
Межпредметные связи при изучении национальной башкирской культуры и борьбы куреш

\begin{tabular}{|c|c|c|}
\hline № $\Pi / \Pi$ & Предмет & Учебная задача обучающегося в рамках урочной деятельности \\
\hline 1 & Физическая культура & $\begin{array}{l}\text { - изучить тактику и технику борцовского искусства куреш; } \\
\text { - освоить вспомогательные дисциплины: стрельбу из традиционного лука; } \\
\text { национальный конный вид спорта }\end{array}$ \\
\hline 2 & $\begin{array}{l}\text { Урок } \\
\text { «борцовского этикета» }\end{array}$ & $\begin{array}{l}\text { - овладеть моральным кодексом батыра «намыс» (честь, достоинство, доблесть); } \\
\text { - освоить ценностно-смысловые ориентиры: добродетельность, патриотизм, } \\
\text { толерантность, гуманность, нормы традиций и обычаев своего этноса }\end{array}$ \\
\hline 3 & $\begin{array}{l}\text { История и культура } \\
\text { Башкортостана }\end{array}$ & $\begin{array}{l}\text { - изучить свой род, историю своей родины, своего народа; } \\
\text { - знать исторических личностей - батыров башкирской земли; } \\
\text { - исследовать роль батыров в военной истории России; } \\
\text { - изучить легенды и предания о батырах; } \\
\text { - осознать значимость института батырства для государства }\end{array}$ \\
\hline 4 & Музыка и хореография & $\begin{array}{l}\text { - изучить различные виды башкирских песен; } \\
\text { - научиться танцевать башкирские танцы }\end{array}$ \\
\hline 5 & Труд и технология & $\begin{array}{l}\text { - изучить декаративно-прикладное искусство башкирского народа; } \\
\text { - обучиться национальному ремесленному искусству: шорничеству, кузнечному } \\
\text { делу, ювелирному искусству, пчеловодству, войлоковалянию; } \\
\text { - научиться готовить национальные башкирские блюда; } \\
\text { - овладеть башкирским застольным этикетом }\end{array}$ \\
\hline 6 & Семьеведение & $\begin{array}{l}\text { - изучить семейный этикет; } \\
\text { - рассмотреть имущественные права членов семьи и их обязанности; } \\
\text { - выявить положение и роли женщины и мужа в семье; } \\
\text { - научиться передавать семейные традиции и обряды своим детям; } \\
\text { - осознать институт семьи как символ духовной силы батырства }\end{array}$ \\
\hline 7 & Башкирский язык & $\begin{array}{l}\text { - целенаправленно изучать, понимать родной язык и говорить на нем; } \\
\text { - владеть поучительными пословицами, поговорками; } \\
\text { - использовать национальные ресурсы в обучении детей; } \\
\text { - научиться писать и излагать свои мысли на родном языке; } \\
\text { - защищать научно-исследовательские работы и проекты на башкирском языке; } \\
\text { - осознанно использовать родной язык как средство межкультурного гармоничного } \\
\text { общения, культурного обмена знаниями и опытом }\end{array}$ \\
\hline
\end{tabular}

Проведенная диагностика в ходе апробирования программы показала высокий уровень сформированности компонентов национальной культуры (98,9\%). Следовательно, можно сделать вывод о том, что выпускники данного лицея владеют культурно-историческими знаниями своего народа, философией здорового и активного образа жизни, осознают важность традиций и обычаев в своем образовании, твердо противостоят негативным аспектам информационной революции, уверены в себе и в духовном генотипе своих будущих детей.

Таким образом, можно сделать следующие выводы:

1. Национальная борьба куреш выполняет воспитательную, коммуникативную, ценностно-смысловую, мировоззренческую, оздоровительную, рекреационно-культурную функции; ффункцию повышения фризической активности.

2. Национальная борьба куреш основана на культурноисторическом подходе к формированию гармонично развитой личности в школьной образовательной среде.

3. Практикование национальной борьбы куреш как средства духовно-нравственного воспитания в рамках урочной деятельности на основе национально-регионального компонента позволяет прививать школьникам «золотой фонд правил народных уроков жизни истинного борца-батыpa» $[8$, c. 106].
4. Любой национальный вид спорта выступает эффективным механизмом сохранения национальной культуры и развития этноса, закаливает дух и тело ребенка, прививает трудолюбие, силу воли, умение работать во благо общества и государства.

1. Ильин А. Н. Культура общества массового потребления: критическое осмысление. Омск : Изд-во ОмГПУ, 2014. 208 с.

2. Валеев И. И. Педагогика Мустая Карима. 2-е изд., испр. и доп. Уфа : Китап, 2003. 224 с.

3. Юсин А. «Душой исполненный полет...». М. : Физкультура и спорт, 1988. 367 с.

4. Монтень М. Опыты. М. : Изд. центр «Терра», 1991. Кн. 1. 509 c.

5. Волков Г. Н. Педагогика любви : в 2 т. М. : МАГИСТРПРЕСС, 2002. Т. 1. 460 c.

6. Донн Ф. Дрэгер. Современные будзюцу и будо. М. : Агентство «ФАИР», 1998. 368 с.

7. Ахмедьянова А. Х. Онтологические основания совершенствования духа и тела. Уфра : РИЦ БашГУ, 2017. 130 с.

8. Султангареева Р. А. Башкирский народный курэш. Уфа : Китап, 2009. 144 с.

(C) Ахмедьянова А. Х., 2020 